Research Article

\title{
Inherited hemoglobin disorders in an Afro-Amazonian community: Saracura
}

\author{
Greice Lemos Cardoso, Silvania Yukiko Lins Takanashi and João Farias Guerreiro \\ Laboratório de Genética Humana e Médica, Instituto de Ciências Biológicas, \\ Universidade Federal do Pará, Belém, PA, Brazil.
}

\begin{abstract}
The most common hemoglobinopathies, viz, hemoglobins $S$ and $C$, and $\alpha$ - and $\beta$-thalassemias, were investigated through the molecular screening of 116 subjects from the community of Saracura, comprising fugitive African slaves from farms of the municipality of Santarém, in the west of Pará State, Brazilian Amazon. The observed frequency of the $H B B^{\star} S$ gene $(0.9 \%)$ was significantly lower than that encountered in other Afro-derived communities in the region. Concomitantly, the absence of the $H B B^{\star} C$ allele has been reported for most of the Afro-Amazonian communities thus far studied. As remnant populations of quilombos are generally small, the heterogeneous distribution of $H B B^{\star} S$ and $H B B^{\star} C$ alleles among them is probably due to genetic drift and/or founder effect. The observed frequency of $3.7 \mathrm{~kb}$ deletion in Saracura (8.5\%) was consistent with the African origin of the population, with a certain degree of local differentiation and admixture with individuals of Caucasian ancestry, placed in evidence by the occurrence of - -(MED) deletion (1.2\%), a common mutation in Mediterranean regions. As regards $\beta$-thalassemia, among the seven different mutations found in Saracura, three $\beta^{\circ}$ and two $\beta^{+}$mutations were of Mediterranean origin, and two $\beta^{+}$of African. Thus, only $28 \%$ of the local $\beta$-thalassemia mutations found in Saracura were of African origin.
\end{abstract}

Key words: sickle cell disease, thalassemias, Afro-Amazonian.

Received: October 20, 2011; Accepted: January 12, 2012.

\section{Introduction}

Inherited hemoglobin disorders fall into two main groups, namely structural hemoglobin variants and thalassemias. The structural hemoglobin variants mostly result from single amino-acid substitutions in the $\alpha$ or $\beta$ chains. The thalassemias are classified according to the particular globin chains that are ineffectively synthesized into the $\alpha$, $\beta, \delta \beta$, and $\varepsilon \delta \beta$ thalassemias. However, from a public health point of view, only $\alpha$ and $\beta$ thalassemias are sufficiently common to be of importance (Weatherall and Clegg, 2001).

The most common structural hemoglobin variants are hemoglobin S (Hb S beta 6(A3) Glu > Val), hemoglobin C (Hb C beta 6(A3) Glu > Lys) and hemoglobin E (Hb E beta 26(B8) Glu > Lys). Although encountered worldwide, Hb S reaches its highest frequencies in sub-Saharan Africa, the Middle East and parts of the Indian sub-continent, where carrier frequencies range from $5 \%$ to $40 \%$, or more, of the population. Whereas $\mathrm{Hb} \mathrm{C}$ reaches its peak in West Africa, $\mathrm{Hb} \mathrm{E}$ is found in the eastern half of the Indian sub-continent and throughout South-East Asia, where, in some areas, carrier rates may exceed $60 \%$ of the population (Flint et al., 1998; Weatherall and Clegg, 2001).

Send correspondence to João Farias Guerreiro. Laboratório de Genética Humana e Médica, Instituto de Ciências Biológicas, Universidade Federal do Pará, Cidade Universitária Prof. José da Silva Neto, Rua Augusto Corrêa, № 1, 66075-110 Guamá, Belém, PA, Brazil. E-mail: joaofg@ufpa.br. $\beta$-thalassemia results from mutations in $\beta$-globin genes, which lead to a reduction in, or absence of, betaglobin chain synthesis. Most known cases of $\beta$-thalassemia are caused by a large number of point mutations of various types, which affect either the quality or the quantity of RNA produced. Almost all kinds of mutations that reduce synthesis of mRNA have been identified as causing $\beta$-thalassemia. Deletions of the beta-globin gene are uncommon. The spectrum of mutations, which differs among ethnic groups, includes a few common mutations and a variable number of rare ones. $\beta$-thalassemia is prevalent in Mediterranean countries, the Middle East, Central Asia, India, South China and the Far East, as well as countries along the north coast of Africa and in South America. The highest carrier frequency is reported in Cyprus (14\%), Sardinia $(10.3 \%)$ and Southeast Asia. The high gene frequency of beta-thalassemia in these regions is most likely related to selective pressure from Plasmodium falciparum malaria (for a review see Galanello and Origa, 2010).

$\alpha$-thalassemia, the most common single-gene disease in the world, is characterized by the reduction or complete absence of $\alpha$-globin gene expression. Two different deletions - $3.7 \mathrm{~kb}$ and $4.2 \mathrm{~kb}$ - in the $\alpha$-globin gene on chromosome $16 \mathrm{p} 13.3$, which originate from homologous recombination between misaligned chromosomes, are the most common causes of $\alpha$-thalassemia (Higgs et al., 1989; Harteveld and Higgs, 2010). Although $3.7 \mathrm{~kb}$ deletion alpha-2 
$\left(-\alpha^{3.7}\right)$, a deletion of 3804 nts from the alpha2 gene to the alpha1, occurs worldwide, it is most prevalent in some African, Indian, Nepalese, Sardinian, several other Mediterranean, Chinese, and East Asian populations. $4.2 \mathrm{~kb}$ deletion $\left(-\alpha^{4.2}\right)$, involving the alpha2 gene alpha-Thal-2, also spread worldwide, it is more commonly found in Indian, Melanesian, Thai, and some other southeast Asian populations (Harteveld and Higgs, 2010). Like all common globin gene disorders (sickle-cell trait and $\beta$-thalassemia), $\beta$-thalassemia occurrence is highly frequent throughout all the tropical and subtropical regions of the world, whereby the inference that all of these globin-gene disorders (including $\alpha$ thalassemia) are selective, since in some way they protect carriers from the ravages of falciparum malaria. However, prevalence has increased in previously non-endemic areas as a consequence of historical and recent immigration flows, the slave-trade, trading activities and colonization (Harteveld and Higgs, 2010).

Only in the second half of the $18^{\text {th }}$ century were Africans, as slaves, brought to the Amazon region on a steady basis, the estimated number arriving between 1755 and 1820 reaching about 53,000. Their regional distribution was not uniform. Although the concentration in Belém, close to the mouth of the Amazon river, and in the nearby villages was high, there was a gradual reduction in upstream-towns, where commercial activities did not justify the extensive employment of this form of hand-labor (Santos et al., 1999). Evidently about $90 \%$ of the slaves imported into northern Brazil were from Angola, the Congo and Mozambique, and the remainder from Senegambia, Guinea-Bissau, and Cape Verde, along Atlantic-WestAfrica. There are records of a small number from French Guyana and Surinam entering the region, some through the illegal slave trade and others as fugitives (Curtin, 1969; Vergolino-Henry and Figueiredo, 1990).

In accordance with what occurred in other Brazilian regions and South American countries, several communities, the so-called mocambos or quilombos, were founded in the Brazilian Amazon by fugitive slaves, especially in the state of Pará, point of entry of African slaves into the region. As, to date, many of these communities remain relatively isolated, much of their identity is still preserved. From genetic studies undertaken in populations of African descent, the level of isolation and mobility has been evaluated, and the gene contribution from other sources quantified. Briefly, the genetic variability observed in these communities is consistent with their African origin, with some degree of local differentiation and admixture with individuals of Caucasian and/or Amerindian ancestry (Bortolini et al., 1987; Guerreiro et al., 1999; Oliveira et al., 2002).

In this study we report the prevalence of sickle cell hemoglobin ( $\mathrm{Hb} \mathrm{S}$ ), alpha-thalassemia deletion alleles (3.7 $\mathrm{kb}$ deletion, $4.2 \mathrm{~kb}$ deletion, -(alpha)20.5, and -(MED) and beta-thalassemia mutations (-88 (C- > T), -87
(C- > G), -29 (A- > G), Codon 6 (-A), Codon 15 (G- > A), Codon 24 (T- > A), Codon 39 (C- > T), IVS-I-1 (G- > A), IVS-I-6 (T- > C) and IVS-I-110 (G- > A)) in Saracura, a community founded by fugitive African slaves in the municipality of Santarém, the mid-Amazon region, Pará State, Brazil.

\section{Subjects and Methods}

The community of Saracura, formed by African slaves, fugitives from farms of the municipality of Santarém, is located in the rural area, along the left and right margins of the Amazon River, in the western region of the State of Pará, at about $2^{\circ} 25^{\prime} 59^{\prime \prime} \mathrm{S} ; 54^{\circ} 36^{\prime} 38^{\prime \prime} \mathrm{W}$. Blood samples from 116 individuals, representing $50 \%$ of the total population, were collected. $56 \%$ were females with ages varying from nine to 78 years. All the participants gave their written consent.

The presence of $\mathrm{Hb} \mathrm{S}$ and $\mathrm{Hb} \mathrm{C}$ in the blood was first determined by electrophoresis in cellulose acetate $\mathrm{pH}$ 8.09.0, as well as agar electrophoresis $\mathrm{pH} 6.2$, and then confirmed by DdeI and BseRI digestion of a $382 \mathrm{bp}$ amplified globin gene fragment, according to Old et al. (1996) and Akar et al. (1996).

The $\alpha$-globin genotype was determined by identification of $3.7 \mathrm{~kb}, 4.2 \mathrm{~kb}$, - (alpha)20.5 $\left(-\alpha^{20.5}\right)$ and - -(MED) ($-{ }^{\mathrm{MED}}$ ) deletions by means of multiplex gap-PCR (Liu et al., 2000; Chong et al., 2000).

Characterization of $\beta$-thalassemia mutations was by direct genomic sequencing of the $\beta$-globin gene amplified through PCR. A 1.433-kb gene fragment containing exons 1 and 2, as well as $0.802 \mathrm{~kb}$ of flanking sequence, was PCR amplified with primers corresponding to positions 2802 to 2775 and 604 to 631 of the human $\beta$-globin. After purification, PCR products were sequenced, using internal primers to cover those gene regions where common $\beta$-thal mutations are found in African and Mediterranean populations, viz., -88 (C- > T), -87 (C- > G), $-29(\mathrm{~A}->\mathrm{G})$, Codon 6 (-A), Codon 15 (G- > A), Codon 24 (T- > A), Codon $39(\mathrm{C}->$ T), IVS-I-1 (G-> A), IVS-I-6 (T- > C) and IVS-I-110 (G- $>$ A, with an ABI Prism BigDye Terminator Cycle Sequencing Ready Reaction kit (Applied Biosystems, Foster City, CA). Electrophoresis of reaction products was on an automated ABI Prism 3130 sequencer (Applied Biosystems). Allele and genotype frequencies were estimated by gene counting.

\section{Results}

\section{Hemoglobin $\mathrm{S}(\mathrm{Hb} \mathrm{S})$ and hemoglobin $\mathrm{C}(\mathrm{Hb} \mathrm{C})$}

Of the 116 individuals analyzed, two presented the sickle-cell trait $(1.7 \%)$, thereby corresponding to a frequency of $0.9 \%$ for the $H B B^{*} S$ gene. Hemoglobin $\mathrm{C}$ was not encountered. 


\section{$\alpha$-thalassemia}

Among the 116 patients analyzed, 24 (20.7\%) presented $\alpha$-thalassemia. Of these, $20(17.2 \%)$ were heterozygotes $\left(-\alpha^{3.7} / \alpha \alpha\right)$, one $(0.9 \%)$ a homozygote $\left(-\alpha^{3.7} /-\alpha^{3.7}\right)$, and $3(2.6 \%)$ carriers of the - - (MED) deletion (-- $\left.{ }^{\mathrm{MED}} \alpha / \alpha \alpha\right)$. The frequencies of $-\alpha^{3.7}$ and -- ${ }^{\text {MED }}$ deletions were $9.5 \%$ and $1.3 \%$, respectively. Neither $4.2 \mathrm{~kb}$ nor - (alpha) 20.5 deletions were observed.

\section{$\beta$-thalassemia}

$\beta$-thal mutations were observed in 19 out of the 116 individuals $(16.4 \%)$. This corresponded to a spectrum of seven different mutations, three of which, $\beta^{0}$ (IVS-I-1 (G- > A), Codon $39(\mathrm{C}->\mathrm{T})$ and Codon $15(\mathrm{G}->\mathrm{A})$ ), and four $\beta^{+}(-88(\mathrm{C}->\mathrm{T})$, Codon $24(\mathrm{~T}->\mathrm{A})$, IVS-I-110 $(\mathrm{G}->\mathrm{A})$ and IVS-I-6 $(\mathrm{T}>\mathrm{C}))$. Mutations $-87(\mathrm{C}->\mathrm{G}),-29$ (A- $>$ G) and Codon 6 (-A) were not found. Allele frequencies are shown in Table 1.

\section{Discussion}

The low frequency of $\mathrm{HBB}^{*} \mathrm{~S}$ genes observed in Saracura $(0.9 \%)$, although similar to that in the Afro-descendants (quilombo remnants) of Cametá $(0.5 \%)$ and Itamoari $(0 \%)$ counties, Pará State, is significantly lower than in the other Afro-derived communities in Trombetas (6.0\%) and Pacoval (3.6\%), Pará State, and Curiau (4.5\%), Amapá State (Schneider et al., 1987; Bortolini et al., 1992; Guerreiro et al., 1999; Oliveira et al., 2002). The distribution of hemoglobin S in Afro-Brazilian communities from other regions in the northeast, midwest, southeast and south, is also heterogeneous. In some communities, the $H B B * S$ allele is either absent or only at low frequencies, whereas in others, frequencies are high, thus in agreement with expectancies for populations of predominantly African origin. On the other hand, even though absence of the $H B B^{*} C$ allele has also been reported in most of the AfroAmazonian communities so far studied, in Curiau frequency was $6.2 \%$. Although this particular variant is also

Table 1 - Allele frequencies of $\beta$-thalassemia in Saracura.

\begin{tabular}{lcccl}
\hline Mutation & Phenotype & $\mathrm{N}$ & $\%$ & Origin \\
\hline -88 C > T & $\beta++$ & 4 & 1.7 & Africa \\
codon 15 G > A & $\beta 0$ & 3 & 1.3 & Mediterranean \\
codon 24 T > A & $\beta+$ & 1 & 0.4 & Africa \\
codon 39 C > T & $\beta 0$ & 4 & 1.7 & Mediterranean \\
IVS1-nt1 G > A & $\beta 0$ & 2 & 0.8 & Mediterranean \\
IVS1-nt6 T > C & $\beta+/++$ & 3 & 1.3 & Mediterranean \\
IVS1-nt110 G > A & $\beta+$ & 4 & 1.7 & Mediterranean \\
\hline
\end{tabular}

$\beta^{0}$ : complete absence of beta globin on the affected allele; $\beta^{+}$: residual production of beta globin (around $10 \%$ ); $\beta^{++}$: very mild reduction in beta globin production. absent in most of the Afro-Brazilian communities from other regions, it occurred in at least one in each (Oliveira et al., 2002; Auricchio et al., 2007). As remnant quilombo populations are generally small, the occurrence of genetic drift and/or founder effect, as well as admixture with individuals of European and Amerindian ancestry could explain this heterogeneous distribution of the $\mathrm{HBB}^{*} \mathrm{~S}$ and $\mathrm{HBB}^{*} \mathrm{C}$ alleles among these populations.

Even though the paucity of data on thalassemia genotyping at the molecular level in Brazilian populations, particularly Afro-Brazilians, hindered the comparison of results, it was possible to consider that the variability observed in Saracura is consistent with the basic African origin of this population, with a certain degree of local differentiation and admixture with individuals of Caucasian ancestry. Although the frequency of $3.7 \mathrm{~kb}$ deletion (8.5\%) was similar to that observed in Afro-newborns from Salvador, Bahia (11.0\%) (Adorno et al., 2008), as well as Afro-descendants from Campinas, São Paulo (13.0\%) (Sonati et al., 1991) and Porto Alegre, Rio Grande do Sul (12.0\%) (Wagner et al., 2010), it was higher than the frequency found in Euro-descendants from Porto Alegre (2.0\%) (Wagner et al., 2010) and individuals from the urban area of Santarém, PA (3.3\%) (Souza et al., 2009). Gene flow from local non-Afro-individuals was placed in evidence by the occurrence of - - (MED) deletion (1.2\%), a common mutation in Mediterraneans (Higgs and Weatherall, 2009). This is the first report of the prevalence of - - (MED) deletion in Brazilians.

As to $\beta$-thalassemia, among the seven different mutations found in Saracura, the three $\beta^{0}$, (IVS-I-1 (G- > A), Codon $39(\mathrm{C}->\mathrm{T})$ and Codon $15(\mathrm{G}->\mathrm{A})$, and two of the $\beta^{+}$, (IVS-I-110 (G- $>$A) and IVS-I-6 $(\mathrm{T}>\mathrm{C})$, were of Mediterranean origin. The other two $\beta^{+}$mutations $(-88(\mathrm{C}->\mathrm{T})$ and Codon 24 (T-> A) i.e., 28\%, were really of African origin.

The European contribution to the local population, as revealed by distribution of inherited hemoglobin disorders, is in accordance with estimates of interethnic admixture based on Y-DNA and mtDNA polymorphisms. These show that the most important non-African contributions to the structure of South-American quilombos were, as a whole, from European males and Amerindian females. In this specific case, the European male contribution was estimated at $57 \%$ (Palha et al., 2011).

Based on historical genetic data, plausibly the Mediterranean thalassemic mutations found in Saracura are predominantly of Portuguese origin, since these alleles are relatively common in Portugal, as a result of occupation of the country over past centuries by peoples of the Mediterranean region, especially Phoenicians, Greeks, Romans and Arabs (Tamagnini et al., 1993). Gene flow from Portuguese men to African and Amerindian groups, is a well-known social fact in the process of colonization of the Amazon, and has been well documented through estimates of inte- 
rethnic admixture based on Y-DNA and mtDNA polymorphisms (Palha et al., 2011). Furthermore, historical records reveal the introduction of American immigrants, as well as English and German, these to a lesser extent, in a region inhabited by Afro-Amazonian communities in the municipality of Santarém. These immigrants arrived at the end of 1867, thereby establishing Afro-Amazonian relations, with evident inter-ethnic mixing (Funes EA, 1995 Doctoral thesis, University of São Paulo), thereby constituting an additional local source of non-African genes. Finally, historical data also reveal that immigrants from the northeast, especially Ceará State, who went to the Amazon for rubber-tapping or fleeing from the prolonged droughts between 1872 and 1910, were another important factor in the formation of local populations.

\section{Acknowledgments}

This work was supported by the National Council for Scientific and Technological Development (409355/2006-2) and the Federal University of Pará, Brazil.

\section{References}

Adorno EV, Zanette AL, Isa S, Seixas MO, Galvão Reis M and Gonçalves MS (2008) Clinical and molecular characteristics of sickle cell anemia in the northeast of Brazil. Genet and Mol Biol 31:621-625.

Akar N, Akar E, Tastan H and Cin S (1996) Direct detection of HbC (B6 Glu-Lys) by BseRI analysis. Am J Hematol 52:325-326.

Auricchio MTB, Vicente JP, Meyer D and Mingroni-Netto RC (2007) Frequency and origins of hemoglobin S mutation in African-derived Brazilian populations. Hum Biol 79:667677.

Bortolini MC, Weimer TA, Franco MHLP, Salzano FM, Layrisse Z, Schneider H, Schneider MPC and Harada ML (1992) Genetic studies in three South American Black populations. Gene Geogr 6:1-16.

Chong SS, Boehm CD, Higgs DR and Cutting GR (2000) Single tube multiplex PCR screen for common deletional determinants of alpha thalassemia. Blood 95:360-362.

Curtin PD (1969) The Atlantic Slave Trade: A Census. University of Wisconsin Press, Madison, 338 pp.

Flint J, Harding RM, Boyce AJ and Clegg JB (1998) The population genetics of the hemoglobinopathies. Baillieres Clin Haematol 11:1-51.

Galanello R and Origa R (2010) Beta-thalassemia. Orphanet J Rare Dis 5:1-15.

Guerreiro JF, Ribeiro-dos-Santos AKC, Santos EJM, Vallinoto ACR, Cayres-Vallinoto IMV, Aguiar GFS and Santos SEB (1999) Genetical-demographic data from two Amazonian populations composed of descendants of African slaves: Pacoval and Curiau. Genet Mol Biol 22:163-167.
Harteveld CL and Higgs DR (2010) Alpha-thalassemia. Orphanet J Rare Dis 28:5-13.

Higgs DR and Weatherall DJ (2009) The alpha thalassemias. Cell Mol Life Sci 66:1154-1162.

Higgs DR, Vickers MA, Wilkie AOM, Pretorius IM, Jarman OAP and Weatherall DJ (1989) A review of the molecular genetics of the human $\alpha$-globin gene cluster. Blood 73:10801104.

Liu YT, Old JM, Miles K, Fisher CA, Weatherall DJ and Clegg JB (2000). Rapid detection of $\alpha$-thalassemia deletions and $\alpha$-globin gene triplication by multiplex polymerase chain reactions. Br J Haematol 108:295-299.

Old JM (1996) Hemoglobinipathies. In: Elles R (ed) Methods in Molecular Medicine: Molecular Diagnosis of Genetic Diseases. Humana Press, Manchester, pp 169-183.

Oliveira SF, Pedrosa MAF, Sousa SMB, Mingroni-Netto RC, Abe-Sandes K, Ferrari I, Barbosa AAL, Auricchio MTBM and Klautau-Guimarães MN (2002) Heterogeneous distribution of $\mathrm{HbS}$ and $\mathrm{HbC}$ alleles in Afro-derived Brazilian populations. Int J Hum Genet 2:153-159.

Palha TJ, Ribeiro-Rodrigues EM, Ribeiro-dos-Santos AKC, Guerreiro JF, de Moura LS and Santos SEB (2011) Male ancestry structure and interethnic admixture in Africandescent communities from the Amazon as revealed by Y-chromosome STRS. Am J Phys Anthropol 144:471-478.

Schneider H, Guerreiro JF, Santos SEB, Weimer TA, Schneider MPC and Salzano FM (1987) Isolate breakdown in Amazonia: The Blacks of the Trombetas River. Braz J Genet 10:565-574.

Santos SEB, Ribeiro dos Santos AKC, Santos EJM and Guerreiro JF (1999) The Amazon microcosm. Ciênc Cult 51:181-190.

Sonati MF, Farah SB, Ramalho AS and Costa FF (1991) High prevalence of alpha-thalassemia in a black population of Brazil. Hemoglobin 15:309-311.

Souza AE, Cardoso GL, Takanashi SY and Guerreiro JF (2009) Alpha-thalassemia ( $3.7 \mathrm{~kb}$ deletion) in a population from the Brazilian Amazon region: Santarém, Pará State. Genet Mol Res 8:477-481.

Tamagnini GP, Gonçalves P, Ribeiro MLS and Kaeda J (1993) Beta-thalassemia mutations in the Portuguese: High frequencies of two alleles is restricted populations. Hemoglobin 17:31-40.

Vergolino-Henry A and Figueiredo N (1990) A presença africana na Amazônia colonial: Uma notícia histórica. Arq Públ Pará 1:27-66.

Wagner SC, Castro SM, Gonzalez TP, Santin AP, Filippon L, Zaleski CF, Azevedo LA, Amorin B, Callegari-Jacques SM and Hutz MH (2010) Prevalence of common $\alpha$-thalassemia determinants in south Brazil: Importance for the diagnosis of microcytic anemia. Genet Mol Biol 33:641-645.

Weatherall DJ and Clegg JB (2001) Inherited hemoglobin disorders: An increasing global health problem. Bull World Health Org 79:704-712.

Associate Editor: Francisco Mauro Salzano

License information: This is an open-access article distributed under the terms of the Creative Commons Attribution License, which permits unrestricted use, distribution, and reproduction in any medium, provided the original work is properly cited. 